\title{
Slöjd, bildning och profession
}

\author{
Sven Hartman
}

Syftet med denna essä är att diskutera den pedagogiska slöjden i ett bildningsperspektiv. Det sker genom att belysa hur skolslöjden under perioden 1880-1920 formades $i$ spänningsfältet mellan samhällets behov av hantverksutbildning och skolans behov av att använda slöjd som ett pedagogiskt verktyg. Under dessa år diskuterades slöjden ofta $i$ ett bildningsperspektiv även om bildningsbegreppet inte alltid skrevs fram. I texten behandlas olika idéer hämtade från några av de viktigare slöjddebattörerna i Norden. Avslutningsvis diskuteras hur argument från den tidiga debatten om skolslöjden ibland återspeglas $i$ senare tiders debatt om slöjdämnet. I kapitlet används bland annat begreppen bildning, utbildning, halvbildning, hantverksskicklighet, händighet och profession.

\section{Inledning}

När vi som föddes i början av 1940-talet gick vårt andra år i folkskolan fick vi möta skolslöjden för första gången. Inför det stora steget att börja skriva med stålpenna och bläck fick var och en tillverka en penntorkare. Den som jag fick sy bestod av fyra eller möjligen fem rektangulära tyglappar, cirka $10 \times 5 \mathrm{~cm}$ stora. Lapparna klipptes till och syddes ihop med en söm i mitten så att de såg ut som en uppslagen bok. På så sätt kom textilt arbete för mig att förknippas med skrivande av text. En händelse som jag nu tycker ser ut som en tanke.

Jag minns hur min första lärare, fröken Eriksson, försökte lugna de pojkar i klassen, som inte ville befatta sig med nål och tråd. Hon sa, att det minsann inte var något att skämmas för. Till och med kungen ägnade sig åt att brodera när han behövde koppla av från sitt ansträngande arbete med att styra landet. Och så visade hon en bild från någon veckotidning som föreställde Gustav V (18581950) där han satt i en konungslig stol med ett broderi i sina händer.

$\mathrm{Nu}$ var han inte den förste i den svenska regentlängden som visade ett aktivt slöjdintresse. Adolf Fredrik (1710-1771) framställdes förr i skolans historieundervisning som en tämligen menlös figur. I stället för att ge sig ut i krig och dö hjältedöden, föredrog att hålla sig hemma och svarva snusdosor. Det där med snusdosorna framställdes $\mathrm{i}$ historieundervisningen som något löjeväckande. Men i själva verket var detta något som under flera århundraden ingick i det 
furstliga bildningsidealet. Ett märkligt exempel på detta finns bevarat i 1600talsslottet Skokloster. Där lät Carl Gustaf Wrangel 1673 inreda en ljus och rymlig verkstad. Han lät skaffa svarvstolar och svarvstål hos en specialist i Stockholm, alla försedda med eleganta adliga monogram. Från Holland importerades exklusiva verktyg, hyvlar, sågar, borrar, bildhuggarjärn osv. I svarvkammaren fanns en fackman som skötte material och verktyg och som undervisade slottsherrarna. (Knutsson, 1986)

Slöjd ingick av allt att döma i ett mångfacetterat bildningsideal och fanns med i bildningsprogrammet på samma sätt som konst, musik, litteratur, dans, vapenövningar med mera. Detta breda bildningsideal hade sina rötter i renässansen, när "intet mänskligt" skulle vara främmande för den studerande. (Sjöstrand, 1960. s. 69, 105) Denna bildningssyn grep i sin tur tillbaka på antiken, som hyllade ideal som mens sana in corpore sano, en sund själ i en sund kropp.

De bildningsideal man möter i historien är mångfacetterade och har djupa rötter. De har sett olika ut i olika tider; tyngdpunkten har förskjutits från tid till annan. Enligt min mening visar historien att också slöjden kan ses i ett bildningsperspektiv. Detta är utgångspunkten för denna text som ska handla om slöjd, bildning och profession.

\section{Om bildningsbegreppet}

Diskussionen om bildning löper genom hela idéhistorien. Varje tankeinriktning tycks ha drivit sin linje i bildningsfrågan. Det gör att det är svårt att slå fast en bestämd definition av bildningsbegreppet, eftersom olika traditioner har tillfört olika aspekter och framhållit sina speciella ståndpunkter. Somliga har förordat en vid bestämning av vad som ska avses med bildning, andra en mer inskränkt och elitistisk avgränsning. I de nordiska länderna har bildningsbegreppet (på danska: dannelse; norska: danning) fătt ett särskilt genomslag inom olika folkbildningsorganisationer.

Upplysningstidens tänkande har varit en viktig utgångspunkt. Man strävade efter att upprätta en sammanhängande rationalistisk världsbild som svar på mänsklighetens stora frågor. Med förnuft och vetenskap gick man till strid mot okunnighet och vidskepelse. Man verkade för tolerans, tankefrihet och tryckfrihet. Kyrkans inflytande över individ och samhälle utsattes för skarp kritik. Denna period kom att färga bildningsdebatten för lång tid.

Jean-Jaques Rousseaus (1712-1778) syn på bildning var beroende av hans sätt att se på människa och samhälle; människonaturen är god, det rådande samhället är ont. Därav följer att den kunskap som grundas på människans egna erfarenheter är mer värda än dem som förmedlas via samhällets etablerade kunskapskanon. 
Eftersom allt, som tränger in i människans intellektuella medvetande, kommer dit genom förmedling av hennes sinnen, är hennes första förstånd av sinnlig art. Våra första lärare i filosofi är våra fötter, våra händer, våra ögon. Att ersätta dessa med böcker är inte att lära oss att tänka förnuftigt; det är att lära oss lita på andras förnuft, att lära oss tro mycket och ingenting veta. (Rousseau, Émile, eller om uppfostran, s. 130)

Senare tiders slöjdförespråkare brukar påpeka att snickerislöjd ingick i den läroplan som Rousseau förordade för sin tänkta elev Emile. Han förespråkade alltså ett brett humanistiskt bildningsideal omfattande hela människan, både kropp och själ, teori och praktik.

Bildningsidén kom för första gången på allvar att tillämpas på ett folkligt plan av Johan Heinrich Pestalozzi (1746-1827) i början av 1800-talet. Hans bidrag bestod framförallt $i$ att han utvecklade principer och metoder för hur man kunde gå tillväga när man drev skola för folkets barn med bildningsmål i sikte. Han kom att betyda mycket för folkskolornas framväxt i Europa och han påverkade också det folkbildningsarbete som växte fram under senare halvan av århundradet. Samtidigt som hans skrifter översattes och spreds i Norden utvecklade den danske teologen och folkbildaren N.F.S. Grundtvig (1783-1872) sina idéer om folkbildning. Han riktade skarpa angrepp mot latinläroverkens språkexercis och trånga bildningsbegrepp, och mot folkskolans inskränkta tristess. I stället ville han ställa "det levande ord" i centrum och låta det lokala, det nationella och det nordiska kulturarvet utgöra fundamentet för ungdomars bildningsgång. Han förordade ett öppet bildningsbegrepp som kom att utvecklas på litet olika sätt i de olika nordiska länderna. Som framgår senare i texten blev slöjden ett naturligt inslag i folkhögskolornas bildningsprogram.

Den svenska pedagogen Ellen Key (1849-1926) anknöt till upplysningstidens breda bildningsbegrepp och till Grundtvigs idéer om folkbildning. Hennes speciella definition av bildningsbegreppet brukar ofta citeras:

Fakta halka ur allas minne - och fortast ur deras som läst efter mixtur- och teskedssystemet. Men bildning är lyckligtvis icke blott kunskap om fakta, utan enligt en ypperlig paradox: "det, som är kvar, sedan vi glömt allt, vad vi lärt”.

Ju större rikedom av dylikt kvarstannande gods, ju större är behållningen av ett studium; ju flera inre bilder, vibrerande känslor och tankeförbindelser, ju flera ... intryck ... vi blivit fyllda av, ju mera utveckling ha vi genom ett studium vunnit för vår personlighet. (Key, 1900, s. )

Bildning är alltså något annat och mycket mer än faktasamlande eller kunskapsackumulering. 
Den lundensiske filosofen Hans Larsson (1862-1944) betydde mycket för den svenska folkbildningsrörelsen. Han menade att "någon är bildad i samma mån som hans olika förmögenheter äro odlade". Det viktiga är inte att man behåller en massa saker i minnet, mycket av det man lär sig är bara något som man stiger på för att komma vidare. Det finns två sidor i en sådan bildningsresa, menar Larsson. Ligger huvudvikten vid förmögenheternas övning, blir bildningen formell, (i betydelsen formande, utvecklande), ligger den på det innehåll som tillägnas blir bildningen reell (i betydelsen knuten till ett visst innehåll, exempelvis en bestämd kunskapskanon). (Larsson, 1917, s. 40)

Bernt Gustavsson (1996) ansluter till detta sätt att se på bildningens innebörd. Han menar att om man ser på hur bildningsbegreppet har fyllts med innehåll genom tiderna, så kan begreppet sägas ha en subjektiv och en objektiv sida. Det säger dels något om det som förväntas ske med personen under bildningsprocessen och dels något om vad personen lämpligen ska tillägna sig för att bilda sig. Ibland har individens fria utveckling stått $\mathrm{i}$ fokus utan några hänsyn till kulturarv och ämneskanon, och ibland motsatsen. Ett liknande synsätt finns hos den norske historikern Gustav E. Karlsen (2014) när han skriver om begreppet danning. Han menar att man i historien kan skilja mellan bildningsteorier som lagt vikt vid "det formale i betydningen process- och individorientering" och "det materiale i betydningen innhold, tradisjon".

I slöjdundervisningens historia kan man se hur man i debatt och styrdokument direkt eller indirekt hämtat stöd från bildningsbegreppet. Tidvis har tonvikten lagts vid det formella, tidvis vid det reella, eller så har man eftersträvat en balans mellan de två polerna.

\section{Bildning som exkluderande klassmarkör}

Inom mer konservativa tankeriktningar utvecklades under 1800-talet ett speciellt, ofta elitistiskt, sätt att se på bildning. Man lade tonvikten vid den reella bildningsdimensionen, oftast vid ett avgränsat klassiskt och språkdominerat bildningsstoff, mer än vid personliga mognadsprocesser. Antiken betraktades som en svunnen guldålder som det gällde att återknyta till i studierna. Man drog en skarp gräns mellan bildning och utbildning. Vid universiteten studerade man främst för att skaffa sig bildning. Utbildning däremot kunde man skaffa sig vid någon av de högskolor och eller seminarier som hade till uppgift att ge yrkesutbildning. Bildning hade högre status än utbildning.

Inom konservatismen fanns en försiktighet inför idén om breddundervisning. Grundhållningen var att staten av princip endast skulle engagera sig i den offentliga klassens (domare, präster, militärer, läkare med flera) utbildning. För näringsklassen (hantverkare, jordbrukare, företagare med flera) hade staten inget som helst ansvar när det gäller utbildning. Det fick organiseras på annat 
sätt genom privata eller lokala initiativ. Och så skedde också, inte minst när det gällde slöjdundervisning.

Ett sätt att värna universitetens exklusiva bildningsanspråk var att använda argumentet om halvbildning. För den som skulle studera vid universitet eller motsvarande gällde det att dricka djupt ur bildningens källa, eller att helt avstå. Den halvbildade ansågs nämligen lätt gripas av idéer och vilja omstörta samhället. "Med en lärd bildad allmoge kan ingen stat bestå och med en halvlärd är ingen belåten", skrev den svenske nationalskalden Esaias Tegnér. Halvbildningen skulle göra att den svenska allmogen förlorade lusten till sitt eget yrke och ständigt strävade efter att höja sig till högre samhällsklasser, menade han. På så sätt skulle samhällets stabilitet äventyras. (Broberg, 1991)

Sättet att se på bildning och halvbildning har periodvis präglat de spända relationerna mellan företrädare för den akademiska världen och andra "lägre" professioner, exempelvis järnvägstjänstemän, postföreståndare och lärare i den obligatoriska skolan. Detta återspeglas ofta i de professionaliseringsprocesser som drevs av nya yrkesgrupper från och med slutet av 1800-talet.

Det var mot detta tillbakablickande, språkfixerade och exkluderande bildningsideal som Grundtvig en gång vände sig när han talade för det levende ord som ersättning för latinläroverkens och universitetens svarta pedagogik. I Grundtvigs efterföljd har sedan den nordiska folkbildningsrörelsen utvecklat en alternativ bildningssyn. I detta speciella bildningsprogram kom olika slöjdarter med tiden att ingå som en viktig del.

\section{Ett hus med anor}

När den svenska staten under 1860-talet stärkte sitt grepp om folkskolan såg man också till att få igång en effektiv folkskollärarutbildning. Det skedde utifrån den tidens konservativa bildningssyn, vilket innebar att man skapade en kort intensiv utbildning utan några som helst bildningsambitioner. Ludvig Christoffer Anjou (1821-1896) i Linköping var den som symboliskt byggde det lärohus som skulle forma den svenska folkskollärarkåren under senare delen av 1800-talet. Hans sätt att se på bildning kom att påverka folkskolan och lärarutbildningen under många år. Han hade fătt åka till Preussen för att lära sig hur folkskollärarutbildning borde gå till. Enligt de "preussiska regulativen" gällde det att hindra blivande lärare från fördjupande studier. Om ynglingar från de obildade klasserna fick läsa för mycket i fel sorts litteratur kunde det myckna bokläsandet leda till den riskabla halvbildningen. (Eskilsson \& Hartman, 1998)

Litet tillspetsat kan man säga att universiteten i gamla tider tog hand om skolgossar och gjorde dem till studenter och unga män. Folkskollärarseminarierna 
däremot tog emot unga män, som under några år tvangs att bli som skolgossar. De skulle plugga mycket och hårt, men inte studera och själva söka kunskap.

Den syn på bildning, utbildning och halvbildning, som ursprungligen utgick från seminariebyggnaden i Linköping, var ganska spridd under andra halvan av 1800-talet. Folkskollärarnas fackliga organisationer kämpade under många år för att få till stånd en förlängning och fördjupning av utbildningen. I det sammanhanget skulle den pedagogiska slöjden bli betydelsefull. När den svenska slöjdlärarutbildningen för trä- och metallslöjd långt senare skulle ges en nystart fick man märkligt nog flytta in i den gamla seminariebyggnaden i Linköping. Men det är en annan historia. (jfr Borg, 2014)

\section{Professionell kamp}

Snart sagt varje skolreform under 1900-talet kom att innebära ett vidgat professionellt revir för den unga folkskollärarkåren och motsvarande minskning för den traditionstyngda lektors- och adjunktskåren.

Vad är det som stärker en yrkesgrupps professionella status? Man brukar nämna bland annat följande kriterier:

- en behörighetsgivande utbildning och tillgång till kunskapsutveckling

- ett eget avgränsat kunskapsområde och en erkänd autonomi på det området

- en professionell värdeskala.

Ett viktigt inslag i den nordiska utbildningshistorien är att slöjden under en viss period spelade så stor roll såväl i lärarnas professionalisering som i bildningsdebatten och den allmänna pedagogiska utvecklingen. Otto Salomon (1849-1907) och slöjdlärarseminariet på Nääs skulle där komma att spela stor roll från 1880-talet och flera decennier framåt (Salomon, 1884). Men det var inte där och då det började.

\section{De första slöjdutbildningarna}

Slöjdundervisning i någon form har naturligtvis funnits så länge människan slöjdat. Barn följde de vuxna som fanns i deras närhet och såg dem i arbete. De lärde sig själva enligt modellen - se och lär. (Sjöberg, 2011) Det var inte inom det vanliga skolsystemet som den mer organiserade undervisningen i slöjd började. I Sverige väcktes flera riksdagsmotioner om att infoga slöjd på schemat i samband med 1842 års folkskolestadga. Men majoriteten motsatte sig det. Slöjden ansågs vara alltför praktisk i den meningen att kunskapsområdet låg för nära de intressen som fanns i näringslivet, inom jordbruk, handel och olika hantverk. Efter några år blev det emellertid möjligt att inrätta slöjdskolor på frivillig basis. Men sådana slöjdskolor fick bara startas i församlingar som redan 
hade fullständigt utbyggda folkskolor och som dessutom hade överskott i skolbudgeten. (Hartman \& Hartman, 2018)

Under 1840-talet startades en rad mindre slöjdskolor runt om i landet som söndags- och aftonskolor. Ett skäl var att det rådde brist på kvalificerade hantverkare efter det att det traditionella utbildningssystemet med lärlingar och gesäller hade upphört i samband med skråväsendets avveckling. Andra slöjdskolor inriktades på undervisning i olika material och tekniker med anknytning till traditionell hemslöjd, eller husflit som det också kallades. De slöjdskolor och de kurser i olika slöjder som startades under andra halvan av 1800-talet hade inga bildningsambitioner. Här var det fråga om utbildnings-satsningar för att värna om landsbygdens behov av binäringar. Det kunde gälla yrkesutbildning, eller förberedande utbildning för kommande yrkesarbete, eller arbete i hem och hushåll. Undervisningen syftade till att träna handlaget och olika hantverkstekniker. Slöjddebatten i Sverige startade med diskussionen om dessa utbildningsformer.

Flera slöjdskolor hade inledningsvis ett problem, och det var rekryteringen. Det var svårt att få bondsönerna att delta i vissa kurser. De såg det som "en skam, att en rik eller förmögen bondson skulle lära att vara skomakare, skräddare eller sadelmakare". Sådant lämpade sig bara för de så kallade "gerningsmännen". Men smide och snickeri kunde kanske dra fler elever till slöjdskolorna. (Hartman \& Hartman, 2018) Också i Danmark hade man rekryteringssvårigheter till de tidiga försöken med kurser i slöjd och hantverk. (Larsen, 1899) Det var först med den pedagogiska slöjdens införande i folkskolan som undervisning i slöjd fick en allmän spridning.

\section{Nääs - den pedagogiska slöjdens vallfartsort}

Åren mellan 1880 och 1930 var den stora epoken skolslöjdens historia. Då färdades ryktet över jorden om the Swedish sloyd. Men riktigare är kanske att tala om den nordiska skolslöjden. Den pedagogiska slöjdens profet i Sverige, Otto Salomon (1849-1907), inspirerades på ett avgörande sätt av den finske skolpatriarken Uno Cygnaeus (1810-1888) och utvecklade därefter sin metodik parallellt med bland andra den norske slöjdpedagogen Hans Kjennerud i Fredrikshald, den danske slöjdpedagogen Søren Meldgård i Askov och, med tiden i skarp dialog med den danske konkurrenten Aksel Mikkelsen (18491929) i Næstved. (Thorbjörnsson, 1990)

"Odiskutabelt är att Norden blev centrum för en slöjdundervisning som fick världsrykte" skriver Thorsten Lundberg (1986), rektor för slöjdseminariet $\mathrm{i}$ Linköping, i en särskild hälsning med anledning av att Sløjdhøjskolen i Esbjerg firade 100-årsjubileum. 
Otto Salomon hade startat med att driva en slöjdskola för pojkar men övergick efter några år till att inrikta sig på att utbilda lärare i pedagogisk slöjd. Han och andra slöjdpionjärer såg gärna slöjden i ett bildningsperspektiv. Skolväsendets uppgift var att bilda hela människan, att utveckla en sund själ i en sund kropp. Till det kroppsliga räknades att träna goda arbetsställningar och att utveckla handlaget med skarpa verktyg eller nål och tråd. I det perspektivet blev ögats skolning och handens övning lika angelägna som att fostra karaktären och öva intellektet.

Den pedagogiska slöjden betraktades som ett formellt bildningsmedel. Det framgick klart av de övergripande principer som Salomon formulerade för den pedagogiska slöjden. Undervisningens mål var bland annat att:

- lära eleven att tycka om praktiskt arbete och hysa aktning för kroppsarbetet

- utveckla elevens självverksamhet

- vänja eleven vid hederlighet, ordning, noggrannhet och renlighet

- att ge eleven allmän händighet.

Den reella, eller materiella sidan av bildningsprocessen knöts till en modellserie i stigande svårighetsgrad som krävde alltfler och alltmer avancerade färdigheter av slöjdaren. Modellerna skulle finnas i slöjdsalen. Undervisningen skulle gå från det lättare till det svårare, från det enklare till det mera sammansatta. Föremålen som skulle tillverkas kan beskrivas med orden vacker vardagsvara; enkla och hållbara konstruktioner, inga krusiduller och ingen lyx. Det viktiga i sammanhanget var att modellserien var medlet, inte målet, för den pedagogiska slöjden. Detta bidrog sannolikt till att bana väg för den pedagogiska slöjden in $\mathrm{i}$ folkskolan.

Under årens lopp förekom också olika kurser i textilslöjd, vävning, teckning och modellering, hushållsgöromål, gymnastik, lek och idrott, sånglekar, folkdanser och trädgårdsskötsel. Otto Salomon var också en flitig författare av artiklar och böcker om olika pedagogiska frågor. Han gav även ut klassiska pedagogiska texter i svensk översättning av bland andra Rousseau och Pestalozzi. Den livsvärld som skapades på slöjdlärarseminariet var i sig ett helt bildningsprogram. Den kom att betyda mycket för den unga folkskollärarkårens professionella självkänsla. Till Nääs kom inte bara folkskolans lärare och lärarinnor utan även betydande män och kvinnor från hela världen. Man hade nationsfester, spex och andra upptåg, men också högtidliga avslutningar med processioner, tal, diktläsning, fanor och standar. Från studentstaden Lund lär det ha kommit en snorkig förfrågan: Var det verkligen tillåtet för enkla folkskollärare att delta $\mathrm{i}$ sådana begivenheter? 
Det stod ett skimmer över utbildningen på Nääs. Många har på olika sätt försökt beskriva vad det var som gav Näässeminariet en så speciell prägel. (Thorbjörnson, 2014; Alm, 2012) Anders Hammarlund (2013) har visat att verksamheten på Nääs var ett uttryck för Salomons sätt att följa en internationell progressiv rörelse för bildning, i förening med en nytolkning av judisk tradition. Man ville frigöra individen och bejaka moderniteten, men ändå vörda traditionen. Han menar att Nääs kom att få en aktiv roll i formuleringen av svensk nationalism med öppenhet mot andra nationer, inte minst de nordiska. Man anknöt till den förindustriella bondekulturens traditioner med sockendräkter, folklekar och slöjd och inbegrep ett slags vördnad för fäderneärvda nationella dygder som ärlighet, pålitlighet, arbetsamhet, sanningslidelse och liknande. (a.a. s. 261)

I denna anda drevs verksamheten på Nääs på ett strategiskt sätt, som anpassades till tidens utbildningspolitik och bildningsdebatt. Konservativa grupper fick gehör för sina synpunkter genom att den pedagogiska slöjden icke gjordes yrkesförberedande eller på annat sätt innehöll yrkesutbildande moment, utan var allmänt fostrande, det vill säga formellt bildande. Liberala grupper fick gehör för sina progressiva idéer om vikten av att vitalisera skolan och verka för folkbildning och demokratisering.

Kanske var det så, att själva bildningstanken om slöjden som ett formellt bildningsmedel, försvagades när Otto Salomon dog 1907. Med tiden försvann också bildningsbegreppet från den pedagogiska debatten. Kvar blev då modellserien, som svarat för det reella, materiella bildningsinnehållet i Nääsmetodiken, men då utan den visionära bildningstankens dynamik. Modellslöjden blev till mallslöjd. Ingen kunde riktigt fylla tomrummet efter Salomon. I samband med Första världskriget upphörde i stort sett det internationella utbytet. Folkskollärarseminarierna började ge utbildning i slöjd. Slöjden förlorade därmed sin betydelse för folkskollärarnas professionalisering. Andra ämnen tillkom i stället som möjliga vägar att stärka professionen. Traditionerna på Nääs fanns kvar, ena årtiondet efter det andra, men kom av många att upplevas som otidsenliga. Slöjdmetodiken stelnade i sin givna form och gick från att vara normbrytare i ett förstelnat skolsystem, till att uppfattas som ett kantigt och gammaldags inslag $i$ en skola stadd i förändring.

\section{Manlig slöjd och kvinnlig}

När man ser närmare på den tidiga slöjddebatten i Sverige visar det sig att diskussionen främst inriktat sig på slöjdundervisning för pojkar, men att den undervisning som faktiskt kom till stånd till större delen var avsedd för flickor. Det tycks alltså som om visionerna gällde pojkarnas och de unga männens hantverksträning, och där var det tydligen mycket snack och lite verkstad, som 
man säger. Flickornas och de unga kvinnornas träning och färdigheter med nål och tråd var däremot något som man faktiskt inte kunde undvara, så där kom kursverksamheten faktiskt igång. Så såg det $\mathrm{i}$ alla fall ut när det gäller slöjdskolornas kursutbud. På likande sätt förhöll det sig med lärarutbildningen. Den lärarutbildningen för den textila slöjden som fanns på olika håll i landet, fick inte alls samma uppmärksamhet som utbildningen för trä och metallslöjd på seminariet i Nääs.

Ulla Johansson (1987, s. 88 f.) har beskrivit den dubbelmoral som hon menar präglade debatten och de centrala besluten om flickslöjden. Å ena sidan ansågs den vara oerhört viktig, eftersom familjens välbefinnande och hemmets trevnad vilade "på spetsen av kvinnans synål", för att citera ett uttryck som användes i debatten. Ändå fick flickslöjden statsbidrag först 1896, nitton år efter gosslöjden, och då bara hälften så mycket. Argumentet för denna ordning kunde 1898 formuleras så här i riksdagens andra kammare:

Skilnaden emellan undervisningen i slöjd för gossar och undervisningen i slöjd för flickor är den, att den förra är en mer pedagogisk slöjd. Den lämpar sig till omvexling mellan studierna under hela läsetiden. Den qvinliga slöjden är däremot mera en praktisk slöjd och afser att lära flickorna sy en klänning eller laga och lappa vad som behöfves. Detta är något helt annat än gosslöjden. (Johansson, 1987, s.79)

Beslutet föregicks av debatter i riksdagen. Diskussionerna rörde bl.a. i vilken utsträckning det var lämpligt att låta skolan överta hemmens undervisning i praktiska kvinnouppgifter. (Johansson, 1987) Slöjdundervisningens genusindelning är över huvud taget ett intressant problemområde väl värt en egen undersökning, likaså ämnets växlande benämningar, men detta ligger utanför denna artikels fokus.

Sammanfattningsvis tycks 1880-talsidéerna om den pedagogiska slöjden som ett formellt bildningsmedel och som ett sätt att berika skolvardagen och utveckla elevens karaktär, ha tillämpats främst på gosslöjden. De idéer om hantverkskunnande och hushållsnytta, som utvecklades i anslutning till de tidiga slöjdskolorna på 1840-talet, levde däremot kvar i synen på flickslöjden.

\section{Slöjd och folkbildning}

Vår del av världen har bidragit med åtminstone två livskraftiga idéer i utbildningens historia. Den första är den nordiska folkhögskolan i Grundtvigs efterföljd. Den andra är den nordiska traditionen för undervisning i pedagogisk slöjd. Kanske är det så att vi inte tillräckligt har uppmärksammat deras inbördes beroende av varandra. Var och en som har upplevt folkhögskoletraditionen när den var som mest livaktig i mitten av 1900-talet kan lätt se likheter med 
verksamheten på Nääs - den lantliga miljön, internatformen, föredragen, ringlekarna, samkvämen, festerna, den unisona sången, nordismen, vänskapsbanden, värnandet om hantverk i olika former etc. Ett synnerligen brett bildningsspektrum.

Det fanns gott om vävstolar i många folkhögskolor. Per Hartman har dokumenterat hur omfattande undervisningen i slöjd och andra praktisk estetiska ämnen var i svensk folkhögskola och i olika bildningsförbund. (Hartman, 1993; 2003; 2014) Slöjden ingick i de flesta folkhögskolornas bildningsprogram, eller kanske är det riktigare att säga, att slöjden ingick i den folkliga traditionen, den som man i Grundtvigs anda ville återknyta till i människors bildningsprocesser. Man ville, så att säga, ge den folkliga slöjden tillbaka till folket. I lantliga miljöer skapades bildningsprogram bestående av teoretiska studier, kamratlig samvaro, promenader, ringlekar, sång, diktläsning, folkupplysning i olika ämnen, samkväm, fester och - handens arbete inom olika slöjdarter.

När det gäller undervisningens uppläggning kan man säga att folkhögskolornas kurser till en början påminde om de tidiga slöjdskolornas. Slöjden sågs inte som ett formellt bildningsmedel, utan som en viktig utbildning inför kommande insatser i hem och hushåll. Med tiden förändrades slöjdutbildningen på folkhögskolorna. De hushållningsinriktade inslagen minskades. Under mellan- och efterkrigstiden blev i stället smakfrågor alltmer dominerande i undervisningen. Därefter kom en period där eget skapande och personliga uttrycksmöjligheter prioriterades.

Den distinktion man under 1800-talet gjorde mellan bildning och (yrkes)utbildning är uppenbarligen irrelevant i våra dagar. Många studerande söker sig i dag till frivilliga, eventuellt yrkesförberedande, slöjdutbildningar. De vill fördjupa sitt slöjdkunnande, men kanske också påbörja en livslång bildningsprocess inom ett hantverk. I denna process är både handen och anden involverade. Den reella och den formella bildningsdimensionen griper in i varandra.

Hur är det då med bildningsförbundens kurser och studiecirklar med inriktning på slöjd? Efter förebilder från England startades olika bildningsorganisationer ungefär samtidigt som den pedagogiska slöjden utvecklades och fick fäste i Norden. I huvudsak fanns det två verksamhetsformer; föreläsningar och studiecirklar. Men i motsats till folkhögskolorna fanns inte slöjden med från början i denna del av folkbildningsarbetet. Den kom först in under andra hälften av 1900talet. I våra dagar är den mycket omfattande.

Denna studieverksamhet har ofta fått kritik från studieförbund och tillsynsmyndigheter. De har inte varit tillräckligt teoretiskt underbyggda, har det sagts; slöjdandet och skapandet i olika material har dominerat i alltför hög 
utsträckning. För att en slöjdcirkel skulle kunna betraktas som folkbildningsarbete måste den innehålla väsentliga inslag av teoretiskt stoff. Den skepsis som en gång visades mot att slöjdens reella bildningsinnehåll (hantverkskunnandet) när den skulle infogas i folkskolans undervisning, tycks hundra år senare återkomma när administratörer och tillsynsmyndigheter granskar studiecirklarna. Det som sägs känneteckna folkbildningen är att den är "fri och frivillig". Men man kan konstatera att studiecirklarna inom bildningsförbunden haft en mer teoretisk och bunden karaktär när det gäller skapande i olika material, än det som sedan 1960-talet gäller för den obligatoriska skolans undervisning i slöjd. (Hartman, 2003)

\section{Slöjd och bildning i vår tid}

De nordiska ländernas utbyte med andra länder i pedagogiska frågor ändrade karaktär under 1900-talet. Efter Första Världskriget minskade det internationella utbytet allmänt sett. Efter det Andra Världskriget försköts de nordiska ländernas intressefokus i pedagogiska frågor från Tyskland/Österrike till USA och den engelskspråkiga världen. Bildningsbegreppet förlorade därigenom sin aktualitet, eftersom den långa och omfattande debatten om bildning framförallt har utgått från kontinenten. Det innebar att det omfattande FoU-arbete och de utredningar som beredde vägen för de stora utbildningsreformerna, som genomfördes under andra halvan av 1900-talet, skedde i stort sett utan anknytning till bildningsdebatten.

I slutet på 1900-talet fick bildningsbegreppet ändå en kort renässans i Sverige i samband med att ett nytt läroplanstänkande lanserades för det svenska skolsystemet. Huvuddokumentet fick det upplyftande namnet Skola för bildning. (SOU 1992:94) Medvetet anknöt man där till nyhumanistiska bildningsidéer och elitistiska förebilder. Anmärkningsvärt nog bortsåg man i det sammanhanget helt från den bildningsdebatt och de utbildningsformer som i de nordiska länderna hade utvecklats inom folkbildningen. Och handens bildning var det naturligtvis inte heller tal om. Något liknande skedde samtidigt i Norge (Karlsen, 2014) Bildningsretoriken återkom i utbildningspolitiken samtidigt som New Public Management slog igenom. Och det är klart, att i ett system som bygger på mätbarhet, kvantifiering, konkurrens och kontroll måste bildningsbegreppet snedvridas så det mer blir fråga om prestationer och examina, och det har strängt taget ingenting med bildning att göra. "Det finns inga examina $\mathrm{i}$ bildning" konstaterar Sven-Eric Liedman (2010). "Det finns inget slutmål som man kan nå och sedan lugnt luta sig tillbaka i förvissningen att man är färdigbildad." - Bildning är en livslång process.

Jag erinrar mig att man inom svensk slöjdlärarutbildning under en period talade mycket om "slöjdprocessen". Jag undrar om inte en sådan process också kunde 
tänkas utsträckt över lång tid och utvecklas till en fri och oändlig bildningsprocess? Slöjd och bildning, alltså. Eller slöjd som bildning. För visst är det så att våra duktiga slöjdare, efter många års strävande kan ha uppnått en utvecklingsnivå där han eller hon till fullo har odlat sina anlag och sin förmåga $\mathrm{i}$ olika avseenden, för att anknyta till Hans Larssons definition: "någon är bildad i samma mån som hans olika förmögenheter äro odlade". Jag tror att alla slöjdintresserade någon gång hos sig själva kunnat iaktta någon form av slöjdbildnings-process, där man uppnått något, som man förut inte förmått. Kanske har de också i sin närhet haft någon som de ser som förebild och som en djupt bildad slöjdare inom en bestämd slöjdart. Man kan påminna sig namnen på stora slöjdare som till exempel Brita-Kajsa Karlsdotter, Emma Wiberg, Lars Pirak, Karin Larsson, Axel Petersson. Förmodligen är det så att de allra flesta av de största har förblivit anonyma. När man har glädjen att möta sådana företrädare för slöjden märker man att de inte bara ägnat en stor del av sitt liv åt att forma slöjdföremål; de har själva formats och utvecklats av sitt slöjdande. Ett livslångt förvärvande av reell bildning, i form av hantverkskunnande och materialkännedom, är därför oupplösligt förenad med deras formella bildning, det vill säga deras personlighet och livshållning.

Ruhi Tyson (2015) har på visat att bildningsbegreppet är relevant när man i dag beskriver utvecklingsprocesser inom utbildning i praktiska yrken. Mot bakgrund av den pedagogiska slöjdens historia som jag tidigare har skrivit om, menar jag att samma sak borde gälla inom slöjd och hantverk.

Vid akademiska högtider brukade man åtminstone förr i världen tala om universitetet som bildningens hemort på jorden. I dag kanske man hellre talar om excellens och ranking, vilket inte har något med bildning att göra. Ändå tror jag att bildningsretoriken fortfarande kan locka en och annan till universitetssystemet. På ett organisatoriskt plan har detta skett med nästan alla de utbildningar, skolor och seminarier som för ett hundratal år sedan startades för att ge utbildning i olika slöjdarter. De präglades en gång i tiden av tidens levande slöjddebatt och en genomreflekterad bildningssyn, och ofta också av någon karismatisk ledargestalt. Men vad hände ett hundratal år senare när universitetssystemet reformerades och så gott som all postgymnasial utbildning fördes in under den gemensamma högskoleorganisationen?

Utfallet för slöjdens del tror jag blev ganska olika i de nordiska länderna, här skriver jag med utgångspunkt från den svenska situationen. Andra kan bedöma detta bättre än jag, men mitt intryck är att den senaste 25 åren inte har varit gynnsamma för slöjden. Förkunskapskraven till slöjdlärarutbildningen har sänkts, utbildningstiden har kortats, undervisningstätheten minskat och storleken på undervisningsgrupperna har ökat. För att tala i bildningstermer har den 
reella bildningsdimensionen satts på undantag och man tycks lita till något slags allmänt slöjdintresse utan koppling till hantverkskunnande. Till detta kommer att slöjden torde höra till mycket få skolämnen som inte någonstans $\mathrm{i}$ universitetssystemet har en fullt utbyggd forskningsöverbyggnad. När de "konstnärliga ämnena" 2010 fick sin särskilda forskarutbildning räknades slöjden inte dit. Denna utveckling, eller snarare brist på utveckling har skett i en tid när talet om vikten av lärares ämneskunskaper ständigt har framhållits.

$\AA$ andra sidan finns det gott om forskning och även utredningar som visar att skolslöjden uppskattas av eleverna. Den är samtidigt något "urgammalt, modernt och coolt" (Johansson, 2008). Denna komplexitet tycks vara svår för de svenska lärosätena att begripa och inse värdet av. Kanske beror det på att ett brett och djupt bildningsbegrepp saknas i dagens universitetsutbildning.

\section{Referenser}

Alm, A. (2012). Upplevelsens poetik. Slöjdseminariet på Nääs 1880-1940. Lunds universitet.

Borg, K. (2014). "Slöjdlärarutbildning” I: Slöjd, bildning och kultur. Om pedagogisk slöjd i historia och nutid. Stockholm. Carlssons Bokförlag.

Borg, K. (2016). "Vem har makten och ansvaret för utveckling eller avveckling av ett skolämne?" Tilde. Rapport nr. 16, 2016. Institutionen för estetiska ämnen, Umeå universitet.

Broberg, G. (1991). "Bildning och folkutbildning (1800-1914)” I: Gyllene äpplen. Svensk idéhistorisk läsebok. Del 2. Atlantis.

Eskilsson, S. O. \& Hartman, S. (1998). " Så planteras en Chronschough” I Pedagogikhistorisk forskning - perspektiv, betydelse och funktion i dagens samhälle. Dokumentation II. Lärarhögskolan i Stockholm.

Gustavsson, B. (1996). Bildning $i$ vår tid. Om bildningens möjligheter och villkor $i$ det moderna samhället. Wahlström \& Widstrand.

Hammarlund, A. (2013). En bön för moderniteten. Kultur och politik i Abraham Baers värld. Stockholm. Carlssons Bokförlag.

Hartman, P. (1989). Förädlad och sedlig. En studie kring den praktiskt-Estetiska undervisningen i sekelskiftets och 1920-talets folkhögskola. Linköpings universitet.

Hartman, P. (2003). Att bilda med bild. En studie av de praktisk-estetiska studiecirklarnas utveckling. Linköpings universitet. Skapande Vetande.

Hartman, P. \& Hartman, S. (2018). Hantverksskolning eller karaktärsfostran? Den slöjdpedagogiska debatten i Sverige under 1800-talets senare hälft. Techneserien. Forskning $i$ slöjdpedagogik och slöjdforskning. 25(2), 1-39.

Hartman, S. (2012). Det pedagogiska kulturarvet. Stockholm. Natur och Kultur.

Hartman, S. (2014). (red.). Slöjd, bildning och kultur. Om pedagogisk slöjd i historia och nutid. Stockholm. Carlssons Bokförlag.

Johansson, U. (1987). Att skolas för hemmet. Umeå universitet.

Johansson, M. (2008). Slöjdämnet - urgammalt, modernt och coolt. I: Kritisk utbildningstidskrift, 133/134(1-2), 5-13. 
Karlsen, G. E. (2014). "Folkeuniversitetet - mellom styring og danning” I Folkedanningens

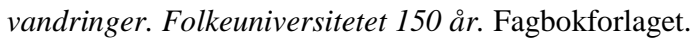

Key, E. (1900/2019). Barnets århundrade. Albert Bonniers förlag.

Knutsson, S. (1986). "Trähantverkarens verktyg. Kring en unik samling 1600-talsverktyg." I: Levande trä. Svenska turistföreningens årsbok 1987. Uppsala. Esselte Herzogs.

Larsen, J. (1899/1984). Danske folkskolens historie. Bidrag till Den danske skoles historie 1818 - 1898. Bind 3.

Larsson, H. (1917/1993). Om bildning och självstudier. ABF förbundet /Bildningsförlaget

Liedman, S.E. (2010). "Bildning och utbildning - vad formar en människa?" I: U. P. Lundgren, R. Säljö \& C. Liberg (2017) (red.), Lärande, skola, bildning. Stockholm. Natur och Kultur.

Lundberg, T. (1986). "Slöjden i Norden” I: Mogensen, H. Slфdlaereruddannelse gennem 100 år. Udgivet $i$ anledning af 100 års jubilceet på sløjdhфjskolen $i$ Esbjerg.

Salomon, Otto (1884). Om slöjden såsom uppfostringsmedel. I: Vår tids forskning, $n r 33$. Stockholm.

Sjöberg, M. (2011). Barnen, skogen och skolan om skolelevers plantering av skog i Sverige ca 1880-1960. Kungl. skogs- och lantbruksakademin/ publikationer. Miscellanea.

Sjöstrand, W. (1960). Pedagogikens historia I. Från antiken till första världskriget. Malmö. Gleerups förlag.

SOU, 1992:94. Skola för bildning: huvudbetänkande av Läroplans-kommittén. Allmänna förlaget.

Thorbjörnsson, H. (1990). Nääs och Otto Salomon slöjden och leken. Helsingborg. OrdBildarna.

Thorbjörnsson, H. (1992). Slöjd och lek på Nääs en bildkrönika om ett kulturarv. OrdBildarna.

Thorbjörnsson, H. (2014). ’Den manliga skolslöjden,

August Abrahamson och Otto Salomon" I: Hartman, S. red. (2014) Slöjd, bildning och kultur. Om pedagogisk slöjd i historia och nutid. Carlssons.

Tyson, R. (2015). Vocational Bildung in action. A case study of the vocational education biography of master craftsman Wolfgang B. Department of Education. Stockholm University.

Sven Hartman är professor emeritus i pedagogik vid universitetet, tidigare lärarhögskolan, i Stockholm. Han har också arbetat med ledning och utveckling av lärarutbildning vid Linköpings universitet där han kom i kontakt med slöjdlärarutbildningen. Hans forskning har bl. a. gällt elevintressen i anslutning till SO-ämnen och utbildningshistoria. 
Slöjdkunnande i förändring - Slöjdkunnande: utmaningar och återupptäckter

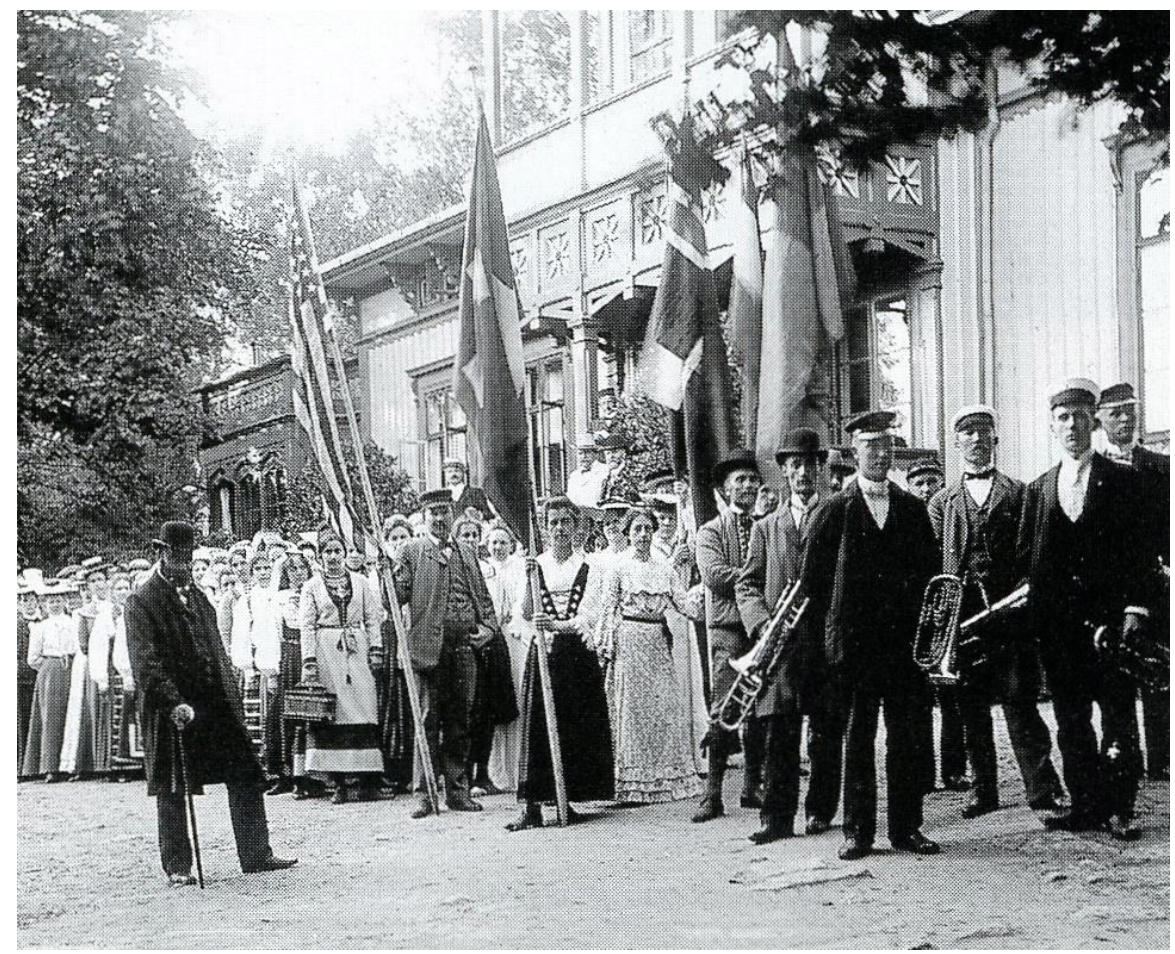

"Detta ständiga tågande!" skriver Hans Thorbjörnsson (1992) som kommentar till denna bild som visar kursdeltagare på väg till

Näässlottspark för att dansa och leka. Otto Salomon till vänster på bilden. 